\title{
組織線維化の進展機序
}

\author{
木村久仁子, 岩 野 正 之
}

\section{Molecular mechanisms of tissue fibrosis}

\author{
Kuniko KIMURA and Masayuki IWANO \\ First Department of Internal Medicine, Nara Medical University
}

(Received April 1, 2009)

\begin{abstract}
summary
Tissue fibrosis is a common cause of organ failure. Consequently, elucidation of the mechanisms underlying both the initiation and progression of fibrosis is an essential step toward establishing new therapeutic strategies for the treatment of organ failure. Fibroblasts are the principal effectors mediating fibrosis and their heterogeneous origins, including epithelial-mesenchymal transition (EMT), bone marrow-derived cell or fibrocyte, and endothelial-mesenchymal transison (EndMT), have been demonstrated. Chronic hypoxia has been proposed as an important microenviromental factor in the development of tissue fibrosis. Recently, we reported that hypoxia induces EMT in renal tubular epithelial cells through activation of hypoxia-inducible factor-1 $\alpha$ (HIF-1 $\alpha)$. Using the Cre-loxP mediated gene targeting of HIF- $1 \alpha$ or VHL which acts as a ubiquitin ligase to promote degradation of HIF- $1 \alpha$, we showed that HIF- $1 \alpha$ plays a key role in the progression of renal fibrosis. As a large number of molecules that contribute to the induction of fibrosis have been identified, and their signal transduction pathway has been characterized, these fibrosis-related molecules have been proposed as therapeutic targets. EMT antagonists, TGF- $\beta$ signal modulator, and HIF-1 $\alpha$ inhbitor could be useful for the treatment of fibrosis.
\end{abstract}

Key words_ fibrosis; fibroblast; epithelial-mesenchymal transition; hypoxia; toll-like receptor

\section{抄録}

組織線維化は臓器不全に共通の病態である。したがって, 線維化の機序を解明することは, 蔵器不全の進展予防 や治療法の開発に重要である. 線維芽細胞は線維化において中心的役割を果たす細胞であるが，その起源として epithelial-mesenchymal transition (EMT)，末梢血前駆細胞・骨髄細胞由来， endothelial-mesenchymal transison (EndMT) などが報告されている. 細胞を取り巻く微小環境において，低酸素は線維化を誘導する重要な因子であ る。われわれは，低酸素刺激が hypoxia-inducible factor-1 $\alpha$ （HIF-1 $\alpha)$ を介して尿細管上皮細胞に EMT を誘導す ることを報告した．さらに，尿細管上皮細胞で特異的に HIF-1 $\alpha$ を欠損あるいは安定発現させた遺伝子改変マウス を用いて，HIF-1 $\alpha$ が腎間質線維化を促進させることを証明した．現在，シグナル伝達系を含む多くの線維化関連 分子が同定され，これらをターゲットとした治療法の開発が進められている. EMT 抑制因子，TGF- $\beta$ シグナル修 飾薬, 抢よび HIF-1 $\alpha$ 活性阻害薬は線維化の新たな治療薬として期待される.

\section{はじめに}

線維化は，障害組織の治癒過程にみられる生体適 応反応である。しかし，過剰な細胞外基質の蓄積は 正常組織を破壊し臓器不全をもたらす。また，線維 化は諸臓器の終末期に共通してみられる病理像であ ることから，疾患の分野を問わず，機序の解明や治 療法の開発に向けての研究が進められている. 線維 芽細胞は線維化病変に集積し, 細胞外基質を産生す
る中心的細胞と考えられる ${ }^{1)}$. 線維芽細胞の由来は 長年不明であったが，近年の遺伝子標識法の進歩に よってその起源が明らかにされつつある. 線維芽細 胞の主な起源として 1) 局所の線維芽細胞の活性化 と増殖，2）上皮細胞からの移行 (Epithelialmesenchymal transition : EMT), 3) 骨髄細胞・末 梢血前駆細胞に由来するものが報告されている，最 近では, 心腎組織に拈いて内皮細胞からの移行 (Endothelial-mesenchymal transition : EndMT) や ペリサイトの関与も報告され，多様性を増している.

線維化に関する研究は, 組織学的特徵である細胞 
外基質の過剰蓄積に関する研究から, 線維芽細胞を 中心とした研究へと展開し, 線維芽細胞を誘導する さまざまな因子の同定やシグナル伝達系が解明され つつある. 一方, 細胞をとりまく微小環境に着目し た際に, 慢性炎症や感染, 虚血・低酸素は線維化を 惹起する重要な因子である.

本稿では, 線維芽細胞の起源について最近の報告 を中心に紹介し，さらに虚血・低酸素や免疫応答を 介した線維化の機序について概説する。 また，近年 試みられている様々な抗線維化療法を紹介する.

\section{I. 線維芽細胞の起源}

従来から線維芽細胞は局所の線維芽細胞が活性化 したものと考えられてきたが，現在はその多様な起 源が明らかとなっている。

\section{Epithelial-mesenchymal transition}

Epithelial-mesenchymal transition（EMT）とは， 上皮細胞がその特異的形質を失い，かわりに間葉系 細胞の形質を発現する現象である。元来，EMT は 胎生期の器官形成過程にみられる現象として知られ てきた。しかし，創傷治癒の過程に EMT が関与し ていることが報告されて以来, 成熟上皮細胞におい ても病的環境下では EMT が認められることが示唆 された。 その後の研究で, transforming growth factor $-\beta(\mathrm{TGF}-\beta)$, epidermal growth factor (EGF), fibroblast growth factor-2 (FGF-2) などの刺激によ って，培養上皮細胞が間葉系細胞の形質を発現する ことが明らかとなった ${ }^{2,3)}$. Iwano らは，生体内に おける EMT 由来線維芽細胞の出現を検討するため に，Cre-loxP システムを用いて近位尿細管上皮細 胞を $\mathrm{LacZ}$ 遺伝子でパーマネント標識した遺伝子改 変マウスを作製した。同マウスに一側尿管結禁 （UUO）で腎間質線維化を誘導しところ，間質線維 化領域には LacZ を発現する線維芽細胞すなわち EMT 由来線維芽細胞が認められた。さらに，間質 線維化領域に認められる線維芽細胞のうち $36 \%$ が EMT に由来する線維芽細胞であったことから, 線 維化に抢けるEMTの重要性が証明されだ).

\section{2. 末梢血前駆細胞・骨髄細胞由来}

Grimm らは，慢性拒絶反応を示した移植腎にレ シピエント由来の筋線維芽細胞が認められることを 報告し，筋線維芽細胞が末梢血前駆細胞あるいは骨 髄細胞に由来する可能性を示した ${ }^{5)}$. 末梢血細胞の
なかには， I 型コラーゲン産生能を有する CD45 お よび CD34 陽性細胞が約 $0.5 \%$ 認められ, fibrocyte と称されている. Fibrocyte は, CCR7, CXCR4, およびCCR2 などのケモカインレセプターを発現 している ${ }^{6,7)}$. Wada らは, CCR7 リガンドである secondary lymphoid tissue chemokine (SLC/CCL21) に対する抗体（抗 CCL21 抗体）やCCR7-null マウ スを用いた研究から, fibrocyteの腎間質への浸潤 機構に CCL21/CCR7 システムが関与していること を明らかにした。また，CCL21/CCR7 は，TGF- $\beta$ や MCP-1/CCL2 産生を介したマクロファージ浸潤 も誘導し, 線維化の進展に関与すると考えられる ${ }^{8}$.

一方, 骨髄細胞の関与を示唆する報告も数多く認 められる.FSP1プロモーター下に EGFPを発現す るトランスジェニックマウスをドナーとして骨髄移 植したマウスに, UUO による腎間質線維化を惹起 すると, 線維化領域に骨髄細胞由来の FSP1 陽性線 維芽細胞が認められる4)。 また，GFPマウスをド ナーとして骨髄移植したマウスにブレオマイシンに よる肺線維症を誘発すると, 線維化領域には多数の コラーゲン産生能を有する GFP 陽性細胞が認めら れることが報告されている9 . 骨髄細胞由来の線維 芽細胞の割合については 10-40\%と報告により異な っている.

\section{Endothelial-mesenchymal transition (EndMT)}

EndMT は胎生期の心蔵の発達段階にみられる現 象であり, 弁や中隔の形成に関わる間葉系細胞が内 皮細胞に由来することで知られている. 心筋線維化 病変の多くは血管周囲や心内膜下に認められること は, 線維芽細胞が内皮細胞に由来することを示唆す る. Zeisberg らは, 内皮細胞で特異的に LacZ が発 現する遺伝子改変マウスに, 大動脈結紮による心筋 線維化モデルを作製した。筋線維化領域に, LacZ を発現する線維芽細胞が認められたことか ら, 線維芽細胞が内皮細胞に由来することが示され た ${ }^{10)}$. 同様に, UUO による腎間質線維化モデルや ストレプトゾトシンによる糖尿病性腎症モデルにお いても，CD31 陽性内皮細胞が線維芽細胞のマー カーである fibroblast specific protein 1 (FSP1) や $\alpha$ smooth muscle actin $(\alpha-$ SMA $)$ を発現することが報 告されている11).

\section{4. pericyte/perivascular fibroblast の関与}

ペリサイトは内皮細胞を裏打ちして血管構造を安 
定に支持する細胞である。Lin らは，コラーゲン type $1 \alpha 1$ のプロモーター下に EGFP の発現が誘導 される遺伝子改変マウスを作製した，正常腎では， 間質領域における EGFP 陽性細胞はペリサイトで あった。また, UUO 後の経時的観察から, 線維化 進展とともにペリサイト周囲に EGFP 陽性かつ $\alpha$ SMA 陽性の細胞が集積することから，筇線維芽細 胞の起源としてペリサイトが有力であるとの仮説を 立てている12).しかし，古典的な病理手法のみによ る検討であるため, 今後, パーマネント遺伝子標識 による証明が必要と思われる.

\section{EMT の機序}

線維化進展におけるEMT の重要性が示されて以 来, 線維化と EMT の関連についての膨大な研究が 行われ，EMTを制御する様々な因子やシグナル伝 達系が解明されてきた ${ }^{13-15)}$. EMT は，1）細胞間お よび細胞-細胞外基質間接着の消失，2）アクチン細 胞骨格の再構成，3）間葉系遺伝子の発現と運動能 の獲得といった多段階のステップを経て生じる現象 である。代表的な adherens junction（AJ) 蛋白で ある E-カドヘリンの消失は，EMTの標準的なマー カーと考えられている. E一カドヘリンの発現を抑 制する転写因子として, Snail1, Slug (Snail2), SIP1，ZEB-1，E12/E47，および Twist などが報告され ている。これらの転写因子は，E-カドヘリンのプ ロモーター領域にある E-boxes に直接結合するこ とでE-カドヘリンの発現を抑制する16-18). 中でも,

EMT 誘導因子としての Snail1 に関する報告は非常 に多い. Snail1 は tight junction（TJ）蛋白である claudin や occludin のプロモーター領域にある Ebox にも直接結合し，その発現を抑制している ${ }^{19)}$.

Snail1 の発現調節については, integrin-linked kinase (ILK) や glycogen synthase kinase $3 \beta$ (GSK$3 \beta)$ の関与が知られている. ILK は, poly-ADPribose polymerase1 (PARP-1) の Snail1 プロモー ターへの結合を促進することで Snail1 の発現を誘 導する，一方，ILKや PARP-1 を阻害すると， Snail1 の発現が抑制されてE-カドヘリンの発現が 維持されることが証明されている20). Phosphoinositide-3-kinase (PI3K)/ILK/Akt による GSK-3 $\beta$ の リン酸化は，ユビキチン・プロテオソーム系を介し た Snail1 の分解を抑制する21)。さらに, Wnt シグ ナルを介した GSK-3 $\beta$ のリン酸化によって, 細胞 質内 $\beta$-catenin が安定化し $\mathrm{T}$-cell specific transcrip- tion factor/lymphoid enhancer factor-1 (TCF/Lef1) と複合体を形成後, 核内に移行して E-カドヘリン の発現を抑制することが報告されている222.

細胞間接着の消失に加えて, 細胞極性の消失は EMT 誘導に重要である. Partitioning-defective protein（Par） 6 は, 細胞極性を制御する TJ 蛋白であ るが，TGF- $\beta$ によるEMT の機序に関与している.

Par6 は TGF- $\beta$ receptor I (T $\beta$ RI) と結合して TJに 存在する. TGF- $\beta$ 刺激により Par6 のセリン残基が リン酸化されると E3 ユビキチンリガーゼである Smad ubiquitin regulatory factors (Smurf) 1 が活性 化される．活性化された Smurf1 はRhoA を分解す ることで, アクトミオシン束が障害され, 細胞極性 が消失する ${ }^{23)}$.

細胞間接着や極性を失った上皮細胞が，運動能を 獲得して組織内に遊走するためには基底膜構造の分 解が必要である. Metalloproteinase-2 (MMP-2) や MMP-9 は, 基底膜の主要成分であるコラーゲ ンIVを基質とすることから，EMTに打ける MMP の関与が示唆される. MMP-2 は TGF- $\beta$ の発現立 進を介して EMT を誘導し, MMP-9の発現低下は 基底膜構造を安定化させて EMT を抑制する24,25). アクチン細胞骨格の再編成には, Rho, Rac, cdc42 などのRhoファミリーの関与が考えられる. MMP-3 は乳腺上皮細胞にアクチン細胞骨格の再編 成を誘導して EMT を惹起するが，Radisky らはそ の機序に Rac サブファミリーに属する Rac1 のスプ ライシング産物である Rac1b が関与していること を報告した ${ }^{26)}$. 細胞の運動能に関わる因子としては lysyl oxidase (LOX), c-MET, CXCR4 が知られてい る.これらは癌細胞の浸潤転移に関連した因子であ り, 細胞の運動能を高めることが示されている. 後 述するように，尿細管上皮細胞は低酸素刺激により EMT が誘導され運動能が亢進するが, LOX 阻害 薬を投与することによってその運動能が抑制される.

\section{III. 低酸素と線維化}

低酸素々線維化には密接な関連があると考えられ てきた. 従来は, 細胞外基質の過唾蓄積による毛細 血管の脱落や酸素拡散の低下の結果, 組織が低酸素 状態になるとの見方が主流であった．最近になり， 腎不全, 心不全, 肺線維症, 強皮症, 肝硬変など組 織線維化をきたす多くの疾患で, 線維化が起こって いない比較的早期の段階から血管のリモデリングや 血流異常, 酸素の需要と供給の不均衡による低酸素 
が存在することが明らかとなり，低酸素の線維化促 進因子としての側面が注目されるようになった27,28).

低酸素による線維化の機序として, 直接的なコ ラーゲンの産生能の充進に加えて, TGF- $\beta$, tissue inhibitor of MMP 1 (TIMP-1), MMP-2 などを介し た細胞外基質の産生六進・分解抑制が報告されてき た29). 最近，われわ机は，低酸素による線維化の新 たな機序として，低酸素による EMT を証明した。 さらに，低酸素応答で中心的役割を果たす hypoxia-inducible factor-1 $\alpha(\mathrm{HIF}-1 \alpha)$ が，低酸素による EMT を介して線維化進展に関与していることをin vitro と in vivoに抢いて明らかにした ${ }^{30,31)}$ 。 また， 低酸素は炎症細胞浸潤を促し, 局所の免疫細胞を賦 活化させることで炎症の増悪・遷延化を誘導して線 維化を進展させる。これら機序にも HIF が関与す ることが証明されている32).

\section{1. 低酸素と EMT}

EMT は, 前述のように線維芽細胞の起源として 重要であり, 線維化進展に深く関与している.われ われは，低酸素による線維化進展の機序に EMT が 関与しているとの仮説を立て，その証明を試みた。 まず，近位尿細管上皮細胞を低酸素下で培養したと ころ, 線維芽細胞様の形態変化が認められ, 上皮細 胞のタイトジャンクション蛋白である ZO-1 の発現 が消失し， $\alpha$-SMAの発現が認められた。また，ス クラッチアッセイでは, 低酸素培養下の尿細管上皮 細胞は，定常酸素培養下の尿細管上皮細胞に比し， 運動能が高いことが明らかとなった。これらの結果 は，低酸素刺激による尿細管上皮細胞の EMT を示 唆するものであった。そこで，より直接的に EMT を検出するために, 近位尿細管上皮細胞が LacZ 遺
伝子でパーマネント標識された遺伝子改変マウスを 作製し，このマウスから単離した近位尿細管上皮細 胞を低酸素下で培養した。 LacZで標識された近位 尿細管上皮細胞が低酸素刺激により線維芽細胞の特 異的マーカーである FSP1 を発現することから，低 酸素によるEMT が証明された ${ }^{30)}$ (図 1).

\section{Hypoxia-inducible factor (HIF) の関与}

生体は, 低酸素刺激に対してエネルギー代謝, 造 血・血管新生, 細胞増殖などに関わる多くの遺伝子 の発現を調節して恒常性を保っている. Hypoxiainducible factor (HIF) は, その中心的役割を果た す転写因子であり, 間接的作用を含めると数千種類 を超える遺伝子の発現を調節していることが分かっ ている.酸素感受性 $\alpha$ サブユニットである $\mathrm{HIF}-1 \alpha$ は, 定常酸素下では von-Hippel Lindau (VHL) 蛋 白によってユビキチン化されプロテアソームにより 速やかに分解されている. 細胞が低酸素にさらされ ると, VHL 蛋白との結合が阻害され, 恒常的に発 現している $\beta$ サブユニットである HIF-1 $\beta$ (ARNT) と 2 量体を形成して核内に移行し, hypoxiaresponsible element (HRE) に結合して標的遺伝子 の発現を誘導する ${ }^{33)}$.われわれは, 低酸素による EMT の機序に HIF-1 $\alpha$ が関与していることを証明 するために，Cre-loxP システムを用いて尿細管上 皮細胞で HIF-1 $\alpha$ を特異的に欠損させた遺伝子改变 マウス（HIF1 $\alpha^{-/-}$マウス）を作製した．このマウ スから得られた近位尿細管上皮細胞（HIF $1 \alpha^{-/-}$ PTECs）を低酸素下で培養したところ，HIF1 $\alpha^{-/-}$ PTECs では低酸素によるEMT が抑制されたこと から，低酸素による EMT に HIF-1 $\alpha$ が関与してい ることが明らかになった ${ }^{30)}$. HIF-1 $\alpha$ による EMT

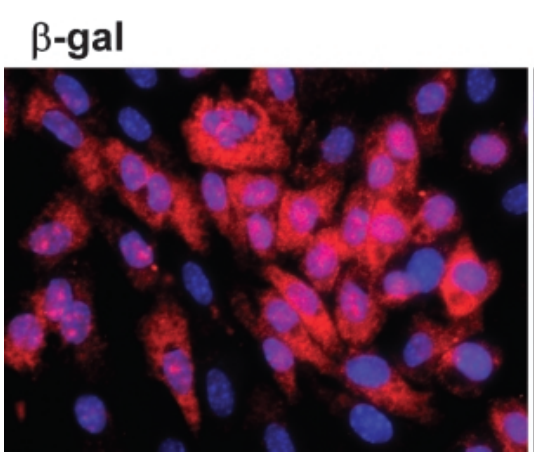

FSP1

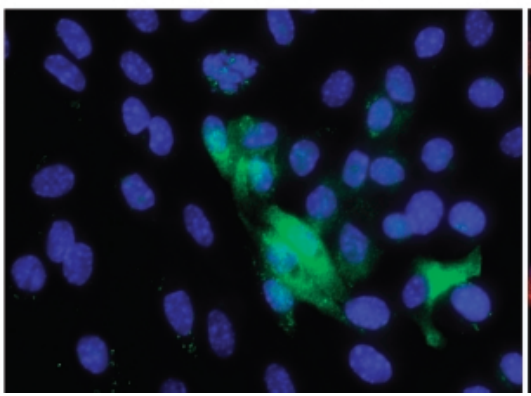

図 1 低酸素刺激によるEMT の誘導

LacZ 遺伝子でパーマネント標識された尿細管上皮細胞を低酸素下で培養すると, $\beta$-gal で染色される尿細管上皮細胞（左）が 線維芽細胞のマーカーである FSP1（中央）を発現し，二重染色で $\beta$-gal と FSP1 を発現する細胞（右, 矢印）が認められる.

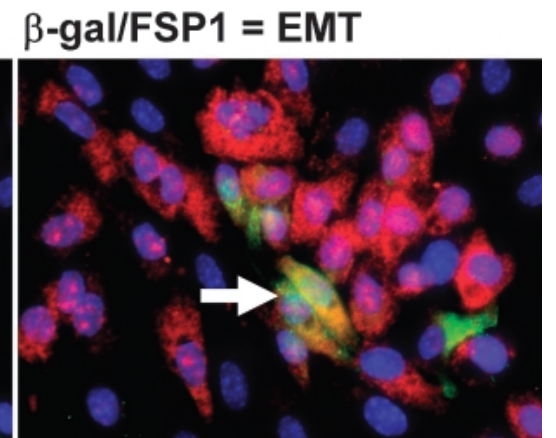

$\beta-\mathrm{gal}$ で染色される尿細管上皮細胞（左）
発現する細胞（右，矢印）が認められる. 


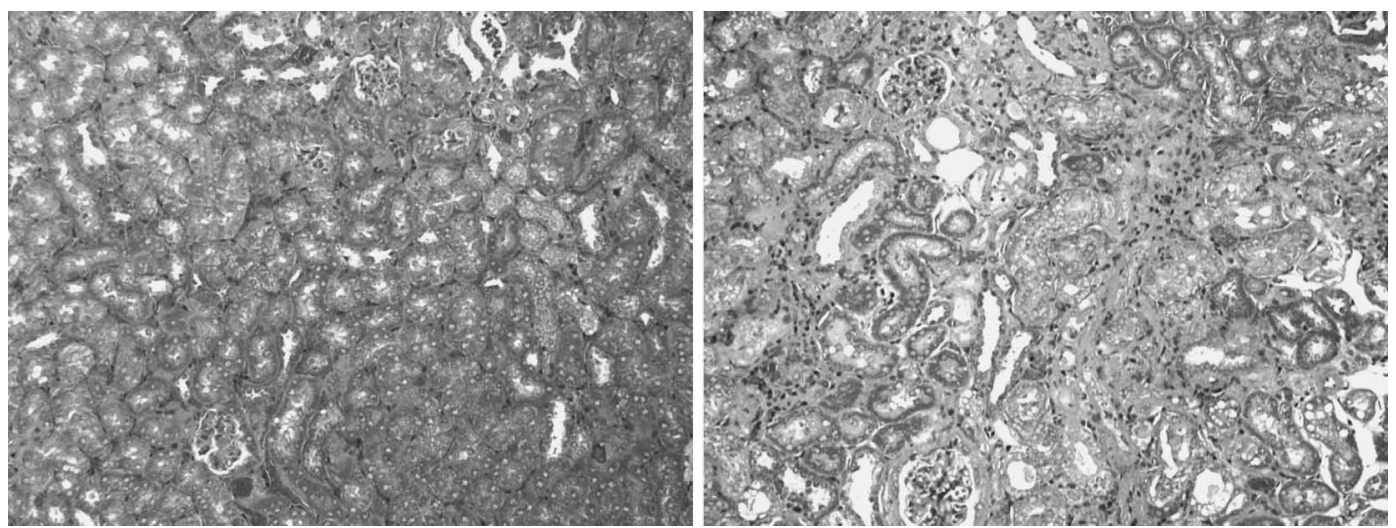

図 2 HIF-1 $\alpha$ 安定発現による線維化の誘導

$\mathrm{VHL}^{+1+}$ マウス（左）と VHL-/- マウス（右）で 96 週間自然経過を観察したところ，コントロールマウスでは線維化がほと んど認められないのに比し， $\mathrm{VHL}^{-1-}$ マウスでは腎間質線維化が誘導される

誘導の機序についてはさらなる検討が必要であるが, HIF-1 $\alpha$ は CTGF, LOX, CXCR4, c-Met などの EMT 関連遺伝子の発現を誘導することから ${ }^{33-36)}$, これらの遺伝子が HIF-1 $\alpha$ による EMT の機序に関 与している可能性が考えられる.

次に, in vivo に抢ける HIF-1 $\alpha$ の線維化に及ぼ す作用を明らかにするために, HIF $1 \alpha^{-/-}$マウスに UUO による腎間質線維化モデルを作製した。

HIF $1 \alpha^{-1-}$ マウスでは, コントロールマウスに比し て間質線維化が有意に抑制された ${ }^{30)}$ 。一方，近位尿 細管上皮細胞で VHL 遺伝子を欠損させ， HIF-1 $1 \alpha$ を安定発現させた遺伝子改变マウス $\left(\mathrm{VHL}^{-1}{ }^{-1}\right.$ マ ウス）では，コントロールマウスに比して線維化が 有意に高度であった ${ }^{31)}$ （図 2）。以上の結果から， HIF-1 $\alpha$ は in vivoに扔いて線維化進展に重要な役 割を果たすことが証明された。

HIF は虚血・低酸素に対して erythropoietin (EPO) や vascular endothelial growth factor （VEGF）など造血や血管新生に関与する遺伝子の 発現を誘導することによって低酸素状態を解除し， 線維化を抑制させることも考えられる．プレコンデ ィショニングによって HIF を活性化させると, 虚 血再還流モデルによる腎障害が軽減することや，コ バルトによる HIF の安定化が腎間質線維化を抑制 するとの報告がある37,38)。最近，EPOの発現は HIF のもうひとつの $\alpha$ サブユニットである HIF- $2 \alpha$ により誘導されることが明らかにされた ${ }^{39-41)}$. HIF が線維化の進展と抑制の両方向に作用するというの は矛盾した現象に思われるが，慢性虚血による尿細 管上皮細胞での HIF-1 の安定化は線維化を進展す

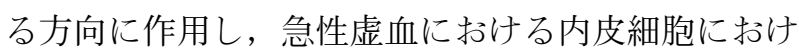

る HIF-2 の安定化は虚血解除により線維化を抑制 する方向に作用すると考えるべきである.

\section{IV. 免疫学的機序による線維化}

慢性炎症は線維化を進展させる要素として重要で ある。慢性炎症の発症機序には toll-like receptor (TLR)を介した免疫応答が関与すると考えられる. TLR はマクロファージ, 樹状細胞, 好中球, B 細 胞, ナチュラルキラー細胞などの細胞表面に存在 する受容体蛋白で, 種々の病原体を認識し自然免 疫を作動させる。TLR は LPS や鞭毛のフラジェ リンなどの pathogen-associated molecular patterns （PAMPs）や細胞や組織の障害によって産生され る内因性分子（damage-associated molecular patterns：DAMPs）をリガンドとして認識する ${ }^{42,43)}$. 代表的な DAMPs として, heat-shock proteins や high-mobility group box 1 (HMGB1) などの細胞内 蛋白, ヒアルロン酸や biglycan などの細胞外基質 由来のフラグメント, 壊死細胞から放出される尿酸 などのプリン代謝産物が報告されている ${ }^{42-45)}$.

DAMPs/TLR を介したシグナルは, IFN regulatory factor や NF- $\kappa \mathrm{B}$ を活性化し, IFN- $\alpha$, IL-1, IL-6 などの炎症性サイトカインおよびマクロファージや 好中球浸潤を誘導するケモカインの発現を誘導する ことで炎症を惹起させる.さらに, DAMPs/TLR シグナルは, MHC による抗原提示能を高め, $\mathrm{T}$ 細 胞を介した免疫応答を誘導する ${ }^{42)}$. 近年, 腎や肝の 虚血再還流モデルに抢いて，HMGB1 やヒアルロン 酸などの DAMPs の発現が充進していることが示 され，これらが TLR-2 や TLR-4を介して, 虚血 再還流による組織障害を誘導することが報告されて 
いる45-47)。 また，TLR-4 が $\mathrm{MyD} 88 / \mathrm{NF}-\kappa \mathrm{B}$ シグ ナル系を介して TGF- $\beta$ の偽受容体である BMP and activin membrane-bound inhibitor (Bambi) の発現 を抑制し，TGF- $\beta$ シグナルを増強させることによ って肝線維化を促進させることが示されている48).

TLR が慢性炎症反応に関与することは明らかであ るが，直接的な線維化との関連を示した報告は少な い. 今後の検討により, 線維化の進展に打ける TLRの位置づけを明確にすることが，線維化の新 しい治療法を開発する上で重要と思われる.

\section{V. 抗線維化療法の試み}

線維化の進展機序が解明されるにつれて, シグナ 儿伝達系を含む多くの線維化関連分子が同定され， これらを標的とした治療法の開発が進められている. EMT の抑制は，線維化の抑制だけでなく，組織の 構造と機能維持にも重要である. EMTを抑制する 因子として hepatocyte growth factor (HGF) および bone morphogenic protein-7 (BMP-7) が知られて いる. HGF は，Smad 抑制因子である SnoN の発 現を誘導することにより $\operatorname{Smad} 2 / 3$ の作用を減弱さ せて EMTを抑制する49,50)。また， BMP-7 は Smad1/5を介して mesenchymal-epithelial transiton （MET）を誘導することで，TGF- $\beta$ による EMT 誘 導作用と拮抗することが報告されている51). 両者と も，動物実験モデルにおいて線維化抑制作用が確認 されている，最近では， BMP-2 やC-peptide が $\mathrm{TGF}-\beta$ シグナルを修飾することにより $\mathrm{EMT}$ を抑 制することが報告されている ${ }^{52,53)}$.さらに，T $\beta$ RI インヒビターやILK インヒビターなどの阻害剤に よるEMTの抑制効果が証明されている20,54).

わ狋れは，HIF-1 $\alpha$ が低酸素による EMTを誘 導し線維化を促進させることから, HIF- $1 \alpha$ の活性 抑制が線維化の新たな治療法となりうるかを検討し た．正常マウスにUUOによる間質線維化モデルを 誘導し，HIF-1 $\alpha$ インヒビターを投与したところ， $\mathrm{HIF}-1 \alpha$ インヒビター投与群ではコントロール群に 比して, 線維芽細胞が有意に減少し間質線維化が抑 制された ${ }^{31)}$. HIF は，癌の浸潤転移の機序に密接 に関わっていることから，癌領域ではすでに多くの HIF 活性阻害薬が開発され臨床応用されつつあ る55).これらの薬剤は, 将来的に線維化の新たな治 療薬となりうる可能性がある。 また, 今後は, 線維 化の治療効果を判定しうる簡便かつ有効なマーカー の開発も必須である.

\section{おわりに}

先進国における全死因のうち, 組織線維化に起因 する臓器不全が $40 \%$ 以上を占めている。したがっ て, 線維化の進展機序に関する研究および線維化に 対する新しい治療法の開発は, 近い将来, 医学研究 の最重要課題となるであろう. 線維化は炎症の治癒 過程に生じる合理的な生体反応とも考えられること から，単純に線維化を抑制することのみが個体にと って有益とは限らない. より詳細な線維化の発症・ 進展メカニズムを解明し, 個々の標的分子に対する 地道な研究を蓄積することが重要であろう.

\section{文献}

1) Iwano M, Fischer A, Okada H, et al. : Conditional abatement of tissue fibrosis using nucleoside analogs to selectively corrupt DNA replication in transgenic fibroblasts. Mol Ther 3 : 149159, 2001.

2) Okada H, Danoff TM, Kalluri R, et al. : Early role of Fsp1 in epithelial-mesenchymal transformation. Am J Physiol 273 : F563-574, 1997.

3) Strutz F, Zeisberg M, Ziyadeh FN, et al. : Role of basic fibroblast growth factor-2 in epithelialmesenchymal transformation. Kidney Int $\mathbf{6 1}$ : 1714-1728, 2002.

4) Iwano M, Plieth D, Danoff TM, et al. : Evidence that fibroblasts derive from epithelium during tissue fibrosis. J Clin Invest 110 : $341^{-}$ 350, 2002.

5) Grimm PC, Nickerson P, Jeffery J, et al. : Neointimal and tubulointerstitial infiltration by recipient mesenchymal cells in chronic renalallograft rejection. $N$ Engl J Med 345 : 93-97, 2001.

6) Moore BB, Kolodsick JE, Thannickal VJ, et al. : CCR2-mediated recruitment of fibrocytes to the alveolar space after fibrotic injury. $A m J$ Pathol 166 : 675-684, 2005.

7) Phillips RJ, Burdick MD, Hong $\mathrm{K}$, et al. : Circulating fibrocytes traffic to the lungs in response to CXCL12 and mediate fibrosis. $J$ Clin Invest 114 : 438-446, 2004.

8) Sakai N, Wada T, Yokoyama H, et al. : Secondary lymphoid tissue chemokine (SLC/ CCL21)/CCR7 signaling regulates fibrocytes in renal fibrosis. Proc Natl Acad Sci U S A 103 : 14098-14103, 2006.

9) Hashimoto N, Jin H, Liu T, et al. : Bone mar- 
row-derived progenitor cells in pulmonary fibrosis. J Clin Invest 113 : 243-252, 2004.

10) Zeisberg EM, Tarnavski O, Zeisberg M, et al. : Endothelial-to-mesenchymal transition contributes to cardiac fibrosis. Nat Med 13 : 952-961, 2007.

11) Zeisberg EM, Potenta SE, Sugimoto H, et al. : Fibroblasts in kidney fibrosis emerge via endothelial-to-mesenchymal transition. J Am Soc Nephrol 19 : 2282-2287, 2008.

12) Lin SL, Kisseleva T, Brenner DA, et al. : Pericytes and perivascular fibroblasts are the primary source of collagen-producing cells in obstructive fibrosis of the kidney. Am J Pathol 173 : 1617-1627, 2008.

13) Iwano $M$, Neilson EG. : Mechanisms of tubulointerstitial fibrosis. Curr Opin Nephrol Hypertens 13 : 279-284, 2004.

14) Kalluri R, Neilson EG. : Epithelial-mesenchymal transition and its implications for fibrosis. J Clin Invest 112 : 1776-1784, 2003.

15) Lee JM, Dedhar S, Kalluri R, et al. : The epithelial-mesenchymal transition : new insights in signaling, development, and disease. $J$ Cell Biol 172 : 973-981, 2006.

16) Batlle E, Sancho E, Franci C, et al. : The transcription factor snail is a repressor of E-cadherin gene expression in epithelial tumour cells. Nat Cell Biol 2 : 84-89, 2000.

17) Cano A, Perez-Moreno MA, Rodrigo I, et al. : The transcription factor snail controls epithelial-mesenchymal transitions by repressing E-cadherin expression. Nat Cell Biol 2 : 7683, 2000.

18) Zavadil J, Bottinger EP. : TGF-beta and epithelial-to-mesenchymal transitions. Oncogene 24 : 5764-5774, 2005.

19) Ikenouchi J, Matsuda M, Furuse M, et al. : Regulation of tight junctions during the epithelium-mesenchyme transition: direct repression of the gene expression of claudins/occludin by Snail. J Cell Sci 116 : 1959-1967, 2003.

20) McPhee TR, McDonald PC, Oloumi A, et al. : Integrin-linked kinase regulates $\mathrm{E}$-cadherin expression through PARP-1. Dev Dyn 237 : 2737-2747, 2008.

21) Schlessinger K, Hall A. : GSK-3beta sets Snail's pace. Nat Cell Biol 6 : 913-915, 2004.

22) Ikeda $S$, Kishida $S$, Yamamoto $H$, et al. : Axin, a negative regulator of the Wnt signaling path- way, forms a complex with GSK-3beta and beta-catenin and promotes GSK-3beta-dependent phosphorylation of beta-catenin. Embo $J$ 17 : 1371-1384, 1998.

23) Ozdamar B, Bose R, Barrios-Rodiles M, et al. : Regulation of the polarity protein Par6 by TGFbeta receptors controls epithelial cell plasticity. Science 307 : 1603-1609, 2005.

24) Cheng S, Lovett DH. : Gelatinase A (MMP-2) is necessary and sufficient for renal tubular cell epithelial-mesenchymal transformation. Am J Pathol 162 : 1937-1949, 2003.

25) Yang J, Shultz RW, Mars WM, et al. : Disruption of tissue-type plasminogen activator gene in mice reduces renal interstitial fibrosis in obstructive nephropathy. J Clin Invest 110 : 15251538, 2002.

26) Radisky DC, Levy DD, Littlepage LE, et al. : Raclb and reactive oxygen species mediate MMP-3-induced EMT and genomic instability. Nature 436 : 123-127, 2005.

27) Manotham K, Tanaka T, Matsumoto M, et al. : Evidence of tubular hypoxia in the early phase in the remnant kidney model. $J A m$ Soc Nephrol 15 : 1277-1288, 2004.

28) Varga J, Abraham D. : Systemic sclerosis : a prototypic multisystem fibrotic disorder. J Clin Invest 117 : 557-567, 2007.

29) Orphanides C, Fine LG, Norman JT. : Hypoxia stimulates proximal tubular cell matrix production via a TGF-beta1-independent mechanism. Kidney Int 52 : 637-647, 1997.

30) Higgins DF, Kimura K, Bernhardt WM, et al. : Hypoxia promotes fibrogenesis in vivo via HIF1 stimulation of epithelial-to-mesenchymal transition. J Clin Invest 117 : 3810-3820, 2007.

31) Kimura K, Iwano M, Higgins DF, et al. : Stable expression of HIF-1alpha in tubular epithelial cells promotes interstitial fibrosis. Am J Physiol Renal Physiol 295 : F1023-1029, 2008.

32) Cramer T, Yamanishi Y, Clausen BE, et al. : HIF-1alpha is essential for myeloid cell-mediated inflammation. Cell 112 : 645-657, 2003.

33) Schofield CJ, Ratcliffe PJ. : Oxygen sensing by HIF hydroxylases. Nat Rev Mol Cell Biol 5 : 343-354, 2004.

34) Ding M, Cui S, Li C, et al. : Loss of the tumor suppressor Vhlh leads to upregulation of Cxcr4 and rapidly progressive glomerulonephritis in mice. Nat Med 12 : 1081-1087, 2006.

35) Erler JT, Bennewith KL, Nicolau M, et al. : 
Lysyl oxidase is essential for hypoxia-induced metastasis. Nature 440 : 1222-1226, 2006.

36) Higgins DF, Biju MP, Akai Y, et al. : Hypoxic induction of Ctgf is directly mediated by Hif -1 . Am J Physiol Renal Physiol 287 : F1223-1232, 2004.

37) Bernhardt WM, Campean V, Kany S, et al. : Preconditional activation of hypoxia-inducible factors ameliorates ischemic acute renal failure. J Am Soc Nephrol 17 : 1970-1978, 2006.

38) Tanaka $T$, Matsumoto $M$, Inagi $R$, et al. : Induction of protective genes by cobalt ameliorates tubulointerstitial injury in the progressive Thy1 nephritis. Kidney Int $\mathbf{6 8}$ : 2714-2725, 2005.

39) Gruber $\mathrm{M}, \mathrm{Hu} \mathrm{CJ}$, Johnson RS, et al. : Acute postnatal ablation of Hif-2alpha results in anemia. Proc Natl Acad Sci U S A 104 : 2301-2306, 2007.

40) Haase VH.: Hypoxia-inducible factors in the kidney. Am J Physiol Renal Physiol 291: F271-281, 2006.

41) Rankin EB, Biju MP, Liu Q, et al. : Hypoxiainducible factor-2 (HIF-2) regulates hepatic erythropoietin in vivo. J Clin Invest 117 : 10681077, 2007.

42) Anders HJ, Banas B, Schlondorff D. : Signaling danger : toll-like receptors and their potential roles in kidney disease. $J$ Am Soc Nephrol 15 : 854-867, 2004.

43) Marshak-Rothstein A. : Toll-like receptors in systemic autoimmune disease. Nat Rev Immunol 6 : 823-835, 2006.

44) Schaefer L, Babelova A, Kiss E, et al. : The matrix component biglycan is proinflammatory and signals through Toll-like receptors 4 and 2 in macrophages. J Clin Invest 115 : 2223-2233, 2005.

45) Tsung A, Sahai R, Tanaka $H$, et al. : The nuclear factor HMGB1 mediates hepatic injury after murine liver ischemia-reperfusion. $J$ Exp Med 201 : 1135-1143, 2005.
46) Leemans JC, Stokman G, Claessen N, et al. : Renal-associated TLR2 mediates ischemia/ reperfusion injury in the kidney. J Clin Invest 115 : 2894-2903, 2005.

47) Wu H, Chen G, Wyburn KR, et al. : TLR4 activation mediates kidney ischemia/reperfusion injury. J Clin Invest 117 : 2847-2859, 2007.

48) Seki E, De Minicis $\mathrm{S}$, Osterreicher $\mathrm{CH}$, et al. : TLR4 enhances TGF-beta signaling and hepatic fibrosis. Nat Med 13 : 1324-1332, 2007.

49) Tan R, Zhang $X$, Yang J, et al. : Molecular basis for the cell type specific induction of SnoN expression by hepatocyte growth factor. $\mathrm{J} \mathrm{Am}$ Soc Nephrol 18 : 2340-2349, 2007.

50) Yang J, Dai C, Liu Y. : A novel mechanism by which hepatocyte growth factor blocks tubular epithelial to mesenchymal transition. J Am Soc Nephrol 16 : 68-78, 2005.

51) Zeisberg $M$, Hanai J, Sugimoto $H$, et al. : BMP-7 counteracts TGF-beta1-induced epithelial-to-mesenchymal transition and reverses chronic renal injury. Nat Med 9 : 964968, 2003.

52) Hills CE, Al-Rasheed N, Al-Rasheed N, et al. : $\mathrm{C}$-peptide reverses TGF-beta1-induced changes in renal proximal tubular cells : implications for treatment of diabetic nephropathy. Am J Physiol Renal Physiol 296 : F614-621, 2009.

53) Yang YL, Liu YS, Chuang LY, et al. : Bone morphogenetic protein-2 antagonizes renal interstitial fibrosis by promoting catabolism of type I transforming growth factor-beta receptors. Endocrinology 150 : 727-740, 2009.

54) Petersen M, Thorikay M, Deckers M, et al. : Oral administration of GW788388, an inhibitor of TGF-beta type I and II receptor kinases, decreases renal fibrosis. Kidney Int 73 : 705715, 2008.

55) Semenza GL. : Targeting HIF-1 for cancer therapy. Nat Rev Cancer 3 : 721-732, 2003. 